\title{
Declining Use of Imaging Modalities Preoperatively in Management of Cryptorchidism in Children
}

\author{
Mohamed Shoukry ${ }^{1}$ and Mona Hemimy ${ }^{2}$ \\ 1. Department of Paediatric Surgery, Royal Manchester Children's Hospital, Central Manchester University Hospitals NHS \\ Foundation Trust, Manchester M13 9WL, UK \\ 2. Department of Radio-diagnosis, Ain Shams University Hospitals, Ain Shams University, Cairo, Egypt
}

\begin{abstract}
Cryptorchidism is characterised by the absence of one or both testes from the scrotum. It is recorded in $30 \%$ of preterm compared to $3 \%$ in term infants. Different radiological modalities have been adopted preoperatively to localise cryptorchid testes. Ultrasound Scan (USS) is the most widely used imaging modality because of availability and non-invasiveness. However, the role of Magnetic Resonance Imaging (MRI) \& Computed Tomography (CT) preoperatively is still unclear. Several studies advocated comparisons between imaging modalities and operative findings. Aim of the study is to perform 35-year literature survey to elucidate trends of imaging studies in investigating cryptorchidism in children. A PubMed search was performed for publications relevant to the pediatric age group, between January 1980 and January 2015. The 35-year search identified a total of 259 articles. Of these, 45 articles that matched the inclusion criteria were retrospective $(n=11)$, prospective $(n=5)$ and other related studies $(n=29)$. Addressed end-points out come: (1) Imaging modality; USS $(n=16)$, MRI $(n=6)$ \& CT $(n=3)$; (2) Sensitivity; USS $(45 \%-96 \%)$, MRI (55\%-86\%) \& CT (94\%); (3) Specificity; USS (25\%-100\%), MRI (79\%-100\%) \& CT (100\%); (4) Accuracy; USS (15\%-91\%), MRI (52\%) \& CT (33\%-96\%); (5) Population size; $(n=838)$; (6) Patients' age; range $(6 \mathrm{~m}-17 \mathrm{y})$. USS has low sensitivity, specificity and accuracy relatively in determining the presence of testes and localisation of their position. Comparatively, MRI has superior role. However, in the presence of examination under anaesthesia and laparoscopic technique, all these modalities are not recommended in investigations preoperatively. Based on the literature review, there is a universal decline trend in performing imaging studies prior to surgery in children with cryptorchidism despite technology improvement.
\end{abstract}

Key words: Undescended testes, cryptorchidism, ultrasound scan, MRI, CT \& children.

\section{Introduction}

Undescended testes (UDT) is recorded in $30 \%$ of preterm compared to $3 \%$ in term infants [1]. Absence of one or both testes from the scrotum is a common congenital anomaly in boys [2]. Initially, neonatologists, general practitioners, health visitors and paediatricians usually get concerned when reviewing boys with suspected undescended testes or empty scrotum [3]. Some clinicians use diagnostic-imaging modalities including Ultrasound Scan (USS), Magnetic Resonance Imaging (MRI) or Computed Tomography (CT) to localise undescended or impalpable testes. The benefits of such investigations should be weighed against irradiation

Corresponding author: Mohamed Shoukry, M.D., consultant surgeon, research fields: MIS, neonatal surgery. risks, costs and burdens on health care system including the need of general anaesthesia in some of these cases. However, USS because of its easy availability and non-invasiveness is the most widely used imaging modality to evaluate boys with UDT prior to paediatric surgical consultation [4].

Since the first prospective review reported by Madrazo et al. in 1979 explaining how USS demonstrated UDT prior to surgery, many works have adopted the idea [5]. Several studies advocated comparisons between different imaging modalities and operative findings in management of children with UDT. Aim of the study is to perform 35-year literature review to elucidate trends of imaging studies in investigating cryptorchidism in children. 


\section{Methods}

\subsection{Data Collection}

A PubMed search was performed for all publications with the key words "Undescended testes, Ultrasound scan, MRI, CT and children". Publications relevant to the pediatric age group, between January 1980 and January 2015, were identified and included in the current study (35 years). Articles were reviewed with regards to information on the following end-points (1) Imaging modality (2) Sensitivity (3) Specificity (4) Accuracy (5) Population size (6) Patients' age.

\subsection{Article Selection}

Potentially relevant studies were selected by screening the titles, abstracts and articles for mentioned relevance key words. The reference list of all relevant articles was also searched. A total of 259 studies were identified in the PubMed search. We used explicit inclusion and exclusion criteria. Language was restricted to English. Studies used with boys with UDT (palpable and impalpable) from infancy to adolescent children under 18 years. Included studies provided preoperative radiological imaging (USS, CT \& MRI) findings compared to operative ones. Excluded articles include case reports and professional opinions. Finally, further 4 articles were excluded due to difficulties to extract data and duplications.

Subsequently, a total of 45 were considered eligible for inclusion. We collected prospective, retrospective and other related studies (Fig. 1). All included articles were read independently. 5 were prospective and 11 were retrospective. 29 were relevant studies concerned with the subject of UDT. Of these related articles, 9 articles dealt with surgical input. The rest 20 concerned with the radiological input.

\subsection{Data Analysis}

We looked at accuracy, sensitivity and specificity of each study $(n=16)$. These articles have been subdivided into two groups according to the radiological modality used. Group (A) includes studies concerned about comparison between preoperative USS on UDT and operative findings. Group (B) includes remaining studies showing the comparison between preoperative all imaging studies (USS, CT and MRI) and operative findings (Tables 1 and 2). Due to data heterogeneity of patient's age \& efficacy of

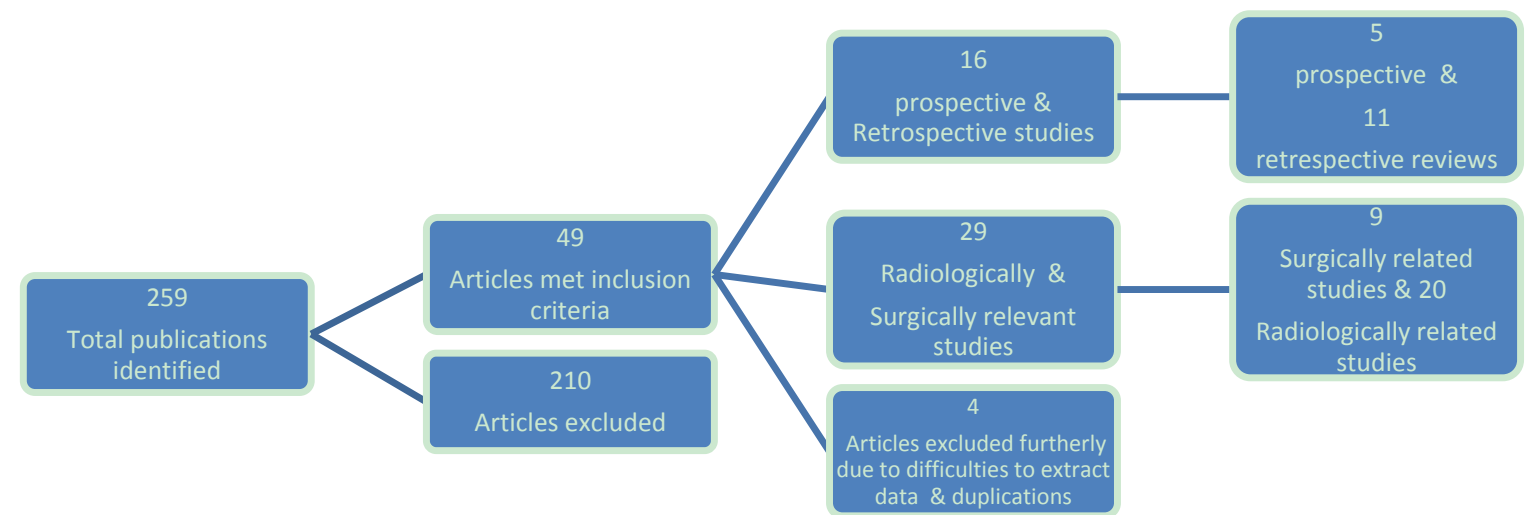

Fig. 1 All articles that included and excluded in the study have been published during the given period 35-year search (Janurary, 1980-Janurary, 2015).

Table 1 Range of sensitivity, specificity and accuracy of preoperative USS dealing with undescended testes in childhood according to the included articles.

\begin{tabular}{llll}
\hline & USS & Palpable UDT & Impalpable UDT \\
\hline Articles included & $n=16$ & $n=9$ & $n=11$ \\
Sensitivity & $45 \%-96 \%$ & $85 \%-95 \%$ & $9 \%-97 \%$ \\
Specificity & $25 \%-100 \%$ & $25 \%-33 \%$ & $48 \%-100 \%$ \\
Accuracy & $15 \%-97 \%$ & $85 \%-97 \%$ & $15 \%-86 \%$ \\
\hline
\end{tabular}


Table 2 Summary of published articles concerned with the role of USS accuracy, sensitivity and specificity in management of UDT preoperatively.

\begin{tabular}{|c|c|c|c|c|c|}
\hline Authors & Source/ year & $n$ & Age & Outcome & Remarks \\
\hline $\begin{array}{l}\text { Shoukry M, Pojak K, } \\
\text { Choudhry MS }\end{array}$ & $\begin{array}{l}\text { Ann R Coll Surg } \\
\text { Engl } \\
\text { 2015 Jan }\end{array}$ & 42 & Median age $6 \mathrm{Y}$ & $\begin{array}{l}\text { Sensitivity and specificity is } 85 \% \text { and } \\
25 \% \text { respectively. PPV of } 88 \% \text { and NPV } \\
\text { Of } 20 \% \text {. }\end{array}$ & $\begin{array}{l}\text { Retrospective } \\
\text { study }\end{array}$ \\
\hline $\begin{array}{l}\text { Adesanya OA, } \\
\text { Ademuyiwa AO, } \\
\text { Bode CO, Adeyomoye AA }\end{array}$ & $\begin{array}{l}\text { J Paediatr urology. } \\
2014 \text { Apr }\end{array}$ & 40 & $\begin{array}{l}\text { Median age } 4 \mathrm{Y} \\
\text { (range } 1-11 \mathrm{Y})\end{array}$ & $\begin{array}{l}\text { Accuracy is } 86.5 \% \text { ( } 90.9 \% \text { palpable and } \\
86.7 \% \text { impalpable testes). Sensitivity is } \\
89.8 \% \text { \& specificity is } 33.3 \% \text {, PPV is } \\
95.7 \% \text { \& NPV is } 16.7 \%\end{array}$ & Prospective study \\
\hline $\begin{array}{l}\text { Ekenze SO, Nwankwo EP, } \\
\text { Okere PC }\end{array}$ & $\begin{array}{l}\text { World J Surg. } \\
2013 \text { May }\end{array}$ & 60 & $\begin{array}{l}\text { Mean age } 5 \mathrm{Y} \\
\text { (range } 1-14 \mathrm{Y} \text { ) }\end{array}$ & $\begin{array}{l}\text { Accuracy with Palpable is } 97.4 \%(P= \\
0.006) \text {. }\end{array}$ & $\begin{array}{l}\text { Retrospective } \\
\text { study }\end{array}$ \\
\hline $\begin{array}{l}\text { Sharifiaghdas F, } \\
\text { Beigi FM. }\end{array}$ & $\begin{array}{l}\text { Scand J Urol } \\
\text { Nephrol. } \\
2008\end{array}$ & 76 & $\begin{array}{l}\text { Mean age } 15.3 \mathrm{Y} \\
\text { (range } 1-39 \mathrm{Y} \text { ) }\end{array}$ & $\begin{array}{l}\text { Accuracy with impalpable UDT is } \\
15.6 \% \text {. }\end{array}$ & $\begin{array}{l}\text { Retrospective } \\
\text { study }\end{array}$ \\
\hline $\begin{array}{l}\text { Nijs SM, Eijsbouts SW, } \\
\text { Madern GC, Leyman PM, } \\
\text { Lequin MH, Hazebroek } \\
\text { FW }\end{array}$ & $\begin{array}{l}\text { Pediatr Radiol. } \\
2007 \text { Apr }\end{array}$ & 135 & -- & $\begin{array}{l}\text { Accuracy is } 68 \% \text { with Impalpable UDT. } \\
\text { Sensitivity is } 97 \% \text { with palpable \& } 48 \% \\
\text { with Impalpable UDT. }\end{array}$ & $\begin{array}{l}\text { Retrospective } \\
\text { study }\end{array}$ \\
\hline $\begin{array}{l}\text { Cain MP, Garra B, } \\
\text { Gibbons MD. }\end{array}$ & $\begin{array}{l}\text { J Urol. } \\
1996 \text { Aug }\end{array}$ & 64 & $\begin{array}{l}\text { Average age } 4.5 \mathrm{Y} \\
\text { (range } 6 \mathrm{M} \text { to } 17 \\
\mathrm{Y} \text { ) }\end{array}$ & $\begin{array}{l}\text { Sensitivity is } 95 \% \text { palpable \& } 9 \% \\
\text { impalpable UDT. }\end{array}$ & $\begin{array}{l}\text { Retrospective } \\
\text { study }\end{array}$ \\
\hline $\begin{array}{l}\text { Graif M, Czerniak A, } \\
\text { Avigad I, Strauss S, } \\
\text { Wolfstein I, Itzchak Y. }\end{array}$ & $\begin{array}{l}\text { Isr J Med Sci. } \\
1990 \text { Jul }\end{array}$ & 45 & -- & $\begin{array}{l}\text { Accuracy is } 97 \% \text { with palpable } \& 75 \% \\
\text { with impalpable UDT. }\end{array}$ & Prospective study \\
\hline $\begin{array}{l}\text { Kullendorff CM, } \\
\text { Hederström E, Forsberg L }\end{array}$ & $\begin{array}{l}\text { Scand J Urol } \\
\text { Nephrol. } \\
1985\end{array}$ & 42 & $\begin{array}{l}\text { Mean age } 62 / 3 \mathrm{Y} \\
\text { (range } 3-12 \mathrm{Y})\end{array}$ & $\begin{array}{l}\text { Accuracy is } 85.4 \% \text { with palpable \& } \\
58.3 \% \text { with impalpable UDT. }\end{array}$ & Prospective study \\
\hline $\begin{array}{l}\text { Madrazo BL, Klugo RC, } \\
\text { Parks JA, DiLoreto R. }\end{array}$ & $\begin{array}{l}\text { Radiology. } \\
1979 \text { Oct }\end{array}$ & 12 & -- & Accuracy is $88.8 \%$ with palpable UDT. & Prospective study \\
\hline
\end{tabular}

radiological modality, we calculate the average outcome for each modality and appeared on the given table.

\section{Results}

The 35-year search identified a total of 259 articles. 45 articles of the total, matched the inclusion criteria. However, further 4 articles were excluded due to difficulties to extract data and duplications. Among the included articles, the target end points are:

(1) Imaging modality; the majority, 16 articles were concerned on the USS role in management of UDT preoperatively. However minority, 6 articles were about the MRI role and only 3 were about the CT imaging results. 2 studies were comparing USS, CT \& MRI imaging performance with surgical findings. All extracted data regarding imaging sensitivity, specificity and accuracy of each study individually have been shown in Tables 1 and 2 .

(2) Sensitivity; USS shows wide range (45\%-96\%) and MRI (55\%-86\%). However, sensitivity of CT was $(94 \%)$ to detect and localize the UDT.

(3) Specificity; USS shows wide range (25\%-100\%). MRI was more precise with relatively wide range specificity (79\%-100\%) compared to the CT out-come $(100 \%)$. One study reported CT specificity while sensitivity has been reported in two articles.

(4) Accuracy; USS reported wide range of $(15 \%-91 \%)$ \& CT (33\%-96\%). However, MRI has been reported of $(52 \%)$.

(5) Population size; across the included article, a total of 838 patients diagnosed with UDT have been calculated.

(6) Patients' age; the range was $(6 \mathrm{~m}-17 \mathrm{y})$ for all the patients in all included studies.

\section{Discussion}

The undescended testis (UDT) could be present at any point along the pathway of normal testicular descent from the retroperitoneum adjacent to the 
kidneys down to the ipsilateral hemiscrotum. However, ectopic testes could be present outside this normal pathway of its descent e.g. superficial inguinal pouch, root of penis, perineum and upper part of thigh or contralateral hemi-scrotum. In 70\%-80\% of cryptorchidism, testes are clinically palpable. The rest that cannot be palpated clinically could be either absent or vanished, located intra-abdominally or in the inguinal canal. Occasionally testes, though palpable, may not be identified on physical examination in an uncooperative or obese child, if the testis is very small or in a scarred groin from previous operations. Associated congenital anomalies as in anterior abdominal wall defects can play a local factor. Precise localisation of these testes preoperatively is crucial in surgical decision making [3].

Since the first report of USS evaluation of UDT published in the 1970s [5], several subsequent studies have been conducted regarding the USS performance in management of UDT preoperatively. Over the last few decades, USS technology has advanced with newer transducers having greater resolution power in order to distinguish testes from adjacent tissues [6]. Kullendorff reported that USS identified $93 \%$ of palpable UDT detected by physical exam. However, in the same prospective series he reported that only $87 \%$ of these were correctly localized using 5 and $7.5 \mathrm{MHz}$ transducers [7]. Wiess et al. reported 70\% [8]. The accuracy rate of USS to identify UDT reported by Graif et al was $90 \%$ [9]. However, Elder et al. in his series reported that USS identified (26.6\%) 12 of 45 palpable UDT [10].

On the other hand, Nijs et al. reported that USS failed to identify (42\%) 14 out of 33 viable intra-abdominal testes, despite the advanced technology and the use of 5 to $12 \mathrm{MHz}$ [11]. So the recent advances in USS technology do not warrant better testicular identification outcome particularly in intra-abdominal ones. Kullendorff reported that USS located $33 \%$ of impalpable testes correctly in the groin and none of them were intra-abdominal [7]. On the other hand, Elder reported that USS was negative in all nonpalpable testes. All these testes were either intra-abdominally or atrophic nubbins on surgical exploration [10].

USS potentially can identify impalpable testes in the groin but not if present intra-abdominally. Thus, USS appears at best, adds little to the physical examination and at worst, provides misleading information [4]. According to meta-analysis and systematic review by Tasian et al., the sensitivity and specificity of USS in identifying the impalpable testes were $45 \%$ and $78 \%$ respectively [15]. However, in the light of results of a recent series by Shoukry et al., the sensitivity and specificity of USS in determining the presence of testes were $85 \%$ and $25 \%$ respectively with PPV of $88 \%$ and NPV of 20\% [16]. Similar results reported by Adesanya et al. (Sensitivity of $89.8 \%$, and specificity of $33.3 \%$, PPV of $95.7 \%$ and NPV of $16.7 \%$ ). USS has overall accuracy of $86.5 \%$ (90.9\% with palpable and $86.7 \%$ impalpable UDT) [17].

USS can usefully often distinguish the various causes of non-painful scrotal masses such as tumours, hydrocele, and meconium peritonitis. It is highly accurate in distinguishing normal from abnormal scrotal contents and in separating testicular from extra testicular masses. However, USS has limitations in distinguishing benign from malignant neoplasms or from some inflammatory lesions. Sonography can be successfully used in the differential diagnosis of the painful scrotum especially with colour flow Doppler. Inflammatory diseases that often involve the epididymis can be distinguished from torsion. Torsion of the appendages has been diagnosed. In cases of scrotal trauma, management decisions are often based on the ultra-sonographic findings [18-20].

Total number of published articles via the PubMed focusing on the role of preoperative USS in management of UDT has declined across decades. However, number of publications that concerned with comparison of preoperative findings between different radiological modalities has increased (Table 2) [5, 7-9, 
11-14, 16, 17].

Several attempts of using other imaging modalities like the Magnetic Resonance Imaging (MRI) or Computed Tomography (CT) have been recognised. This is to identify and localise UDT (Table 3) [21-27]. The outcome results varied according to each modality.

In prospective study by Yeung et al., Gd-MRA has a sensitivity of $96 \%$ and a specificity of $100 \%$ for localizing impalpable UDT compared to USS. USS failed to reveal any intra-abdominal or vanishing testes. But not surprisingly, it correctly localized 90\% of UDT testes within the inguinal canal [21]. The results of two recent retrospective series, reported by Shah et al. and Kanemoto et al. comparing MRI \& USS performance with Impalpable UDT varied [23, 24]. As lower figure, MRI has accuracy of $52 \%$ in localizing impalpable UDT compared to $19 \%$ of USS. The sensitivity of detection was $55 \%$ and $60 \%$ respectively. But, as higher figure, MRI has sensitivity of $86 \%$, a specificity of $79 \%$, and an accuracy of $85 \%$. The USS has sensitivity of $76 \%$, specificity of $100 \%$, and an accuracy of $84 \%$ in the diagnosis of impalpable UDT.

As CT imaging has been introduced earlier than MRI, Wolverson reported that CT has 94\% sensitivity, 100\% specificity and 96\% accuracy in determining UDT compared to USS results. It showed $88 \%$ sensitivity, $100 \%$ specificity and $91 \%$ accuracy [25]. Overall accuracy of all modalities (USS, CT \& MRI) was 44\% published by Hrebinko in 1993 on16 boys. USS findings were correlated with operative findings in $58 \%$ of UDT, while CT \& MRI correlated in only $33 \% \& 0 \%$ respectively [26]. However, Liu and his group in 2002 on 150 boys, reported the overall accuracy of preoperative localization of UDT was $(70.6 \%)$ by image studies (USS, CT \& MRI) [27].

Nevertheless, the irradiation risks, costs and burdens on health care system including the need of general anaesthesia in some of these cases do not warrant the outcome. As the preoperative USS is not reliable in localising nonpalpable UDT and not useful in determining the subsequent surgical management, these radiological imaging modalities should aim far

Table 3 Summary of published articles concerned with comparative results of different imaging modalities USS, CT \& MRI. It shows the available accuracy, sensitivity and specificity values.

\begin{tabular}{|c|c|c|c|c|}
\hline Authors & Source/year & $n$ & Outcome & Remarks \\
\hline Shah A, Shah A. & $\begin{array}{l}\text { Indian Pediatr. } \\
2006 \text { Aug }\end{array}$ & 40 & $\begin{array}{l}\text { Accuracy of USS and MRI with impalpable UDT is } \\
19 \% \text { \& } 52 \% \text { respectively. } \\
\text { Sensitivity is } 60 \% \text { and } 55 \% \text { respectively. }\end{array}$ & $\begin{array}{l}\text { Retrospective study } \\
\text { (USS \& MRI) }\end{array}$ \\
\hline $\begin{array}{l}\text { Kanemoto K, Hayashi } \\
\text { Y,Kojima Y, Maruyama } \\
\text { T, Ito M, Kohri K. }\end{array}$ & $\begin{array}{l}\text { IntJ Urol. } \\
2005 \mathrm{Jul}\end{array}$ & 56 & $\begin{array}{l}\text { Sensitivity of USS is } 76 \% \text {, specificity } 100 \% \& \text { } \\
\text { accuracy } 84 \% \text { with impalpable UDT. } \\
\text { MRI has sensitivity of } 86 \% \text {, specificity of } 79 \% \& \\
\text { accuracy of } 85 \% \text {. }\end{array}$ & $\begin{array}{l}\text { Retrospective study } \\
\text { (USS \& MRI) }\end{array}$ \\
\hline $\begin{array}{l}\text { Liu CS, Chin TW, Wei CF } \\
\text { Zhonghua Yi Xue Za Zhi. }\end{array}$ & $\begin{array}{l}\text { Zhonghua Yi Xue } \\
\text { Za ZHI(Taipei). } \\
2002 \text { Feb }\end{array}$ & 150 & $\begin{array}{l}\text { Overall accuracy of (USS, CT and MRI) with UDT } \\
\text { was } 70.6 \% \text {. } \\
\text { Accuracy of USS is } 96.3 \% \text { with palpable \& } 21.7 \% \\
\text { with impalpable UDT. }\end{array}$ & $\begin{array}{l}\text { Retrospective study } \\
\text { (USS, CT \& MRI) }\end{array}$ \\
\hline $\begin{array}{l}\text { Yeung CK, Tam YH, } \\
\text { Chan YL, Lee KH, } \\
\text { Metreweli C. }\end{array}$ & $\begin{array}{l}\text { J Urol. } \\
1999 \text { Sep }\end{array}$ & 21 & $\begin{array}{l}\text { Accuracy of USS is } 90 \% \text { palpable UDT. } \\
\text { Gd-MRA has sensitivity of } 96 \% \text { \& specificity of } 100 \% \\
\text { with impalpable UDT. }\end{array}$ & $\begin{array}{l}\text { Prospectively study } \\
\text { (USS \& MRA) }\end{array}$ \\
\hline $\begin{array}{l}\text { Maghnie M, Vanzulli A, } \\
\text { Paesano P, Bragheri R, } \\
\text { Palladini G, Preti P, } \\
\text { DelMaschio A, Severi F. }\end{array}$ & $\begin{array}{l}\text { Arch Pediatr } \\
\text { Adolesc Med. } \\
\text { 1994 Jul }\end{array}$ & 17 & $\begin{array}{l}\text { Accuracy of USS is } 62 \% \text { \& MRI } 52 \% \text { with impalpable } \\
\text { UDT. }\end{array}$ & $\begin{array}{l}\text { Retrospective study } \\
\text { (USS \& MRI) }\end{array}$ \\
\hline $\begin{array}{l}\text { Hrebinko RL, Bellinger } \\
\text { MF. }\end{array}$ & $\begin{array}{l}\text { J Urol. } \\
1993 \text { Aug }\end{array}$ & 18 & $\begin{array}{l}\text { Overall accuracy of All radiological imaging was } \\
44 \% \text {. } \\
\text { Accuracy of USS is } 58 \% \text {, CT } 33 \% \text { \& MRI } 0 \%\end{array}$ & $\begin{array}{l}\text { Retrospective study } \\
\text { (USS, CT \& MRI) }\end{array}$ \\
\hline $\begin{array}{l}\text { Wolverson MK, Houttuin } \\
\text { E, Heiberg E, Sundaram } \\
\text { M, Shields JB. }\end{array}$ & $\begin{array}{l}\text { Radiology. } \\
1983 \text { Jan }\end{array}$ & 20 & $\begin{array}{l}\text { USS has } 88 \% \text { sensitivity, } 100 \% \text { specificity \& } 91 \% \\
\text { accuracy. } \\
\text { CT has } 94 \% \text { sensitivity, } 100 \% \text { specificity \& } 96 \% \\
\text { accuracy. }\end{array}$ & $\begin{array}{l}\text { Retrospective study } \\
\text { (USS \& CT) }\end{array}$ \\
\hline
\end{tabular}


than localising UDT [4]. Current United States Department of Health and Human Services guidelines state that the USS, CT and MRI do not provide any additional information to the physical examination in case of palpable testes [28]. However, the role of imaging studies in certain clinical situations is considered helpful diagnostic tool like disorders of sexual development and hypospadias or in the investigation internal genitourinary organs in syndromes and or associated congenital anomalies [29].

Surgical approach for boys with cryptorchidism depends on the presence or absence and the position of testes at the time of examination under anaesthesia prior to the surgical procedure. Single stage open orchidopexy is usually performed for palpable testes using groin or scrotal approach [30, 31]. On the other hand, initial diagnostic laparoscopy is performed for impalpable testes in most of the cases. This is usually followed by single or multi staged orchidopexy if good sized testis is identified using laparoscopic or an open approach [32]. Laparoscopy has proven to be the only diagnostic modality where the findings provide a clear, dependable direction for definitive management of impalpable testes. It allows an accurate diagnosis and simultaneous definitive treatment of various pathologic conditions and positions of the testes, such as low or high intra-abdominal testes [33]. The procedure was accurate in all patients while other imaging modalities (US, CT and MRI) failed to localise the testes in most cases or not informative enough [34-36].

\section{Conclusion}

USS has low sensitivity, specificity and accuracy relatively in determining the presence of testes and localisation of their position. Comparatively, MRI has superior role. However, in the presence of examination under anaesthesia and laparoscopic technique, all these modalities are not recommended in investigations preoperatively. Based on the literature review, there is a universal trend towards the decline in performing imaging studies prior to surgery in children with cryptorchidism despite technology improvement.

\section{Acknowledgments}

Special acknowledgment to Mr Munther Haddad; senior consultant paediatric surgeon at Chelsea and Westminster hospital for his effort and advice regarding the final review.

\section{References}

[1] Cryptorchidism Study Group. 1992. "Cryptorchidism: A Prospective Study of 7500 Consecutive Male Birth 1984-8. John Radcliffe Hospital." Arch. Dis. Child. 67 (7): 892-9.

[2] Canlorbe, P., Lange, J. C., and Borniche, P. 1966. "Cryptorchidism. (Study of 145 Cases). Definition, Frequence, Material." Ann. Pediatr. (Paris). 13 (4): 250-1.

[3] Smolko, M. J., Kaplan, G. W., and Brock, W. A. 1983. "Location and Fate of the Nonpalpable Testis in Children." J. Urol. 129 (6): 1204-6.

[4] Tasian, G. E., Copp, H. L., and Baskin, L. S. 2011. "Diagnostic Imaging in Cryptorchidism: Utility, Indications and Effectiveness." J. Pediat. Surgery 46: 2406-7.

[5] Madrazo, B. L., Klugo, R. C., Parks, J. A., and DiLoreto, R. 1979. "Ultrasonographic Demonstration of Undescended Testes." Radiology 133 (1): 181-3.

[6] Tasian, G. E., Yiee, J. H., and Copp, H. L. 2011. "Imaging Use and Cryptorchidism: Determinants of Practice Patterns." J. Urol. 185 (12): 1882-7.

[7] Kullendroff, C. M., Hederstom, E., and Forsberg, L. 1985. "Preoperative Ultrasonography of Undescended Testis." Scand J. Urol. Nephrol. 19:13-5.

[8] Weiss, R. M., Carter, A. R., and Rosenfield, A. T. 1986. "High Resolution Real-Time Ultrasonography in the Localization of the Undescended Testis." J. Urol. 135 (2): 936-8.

[9] Graif, M., Czerniak, A., Avigad, I., Strauss, S., Wolfstein, I., and Itzchak, Y. 1990. "High-Resolution Sonography of the Undescended Testis in Childhood: An Analysis of 45 Cases." Isr. J. Med. Sci. 26 (7): 382-5.

[10] Elder, J. S. 2002. "Ultrasonography Is Unnecessary in Evaluating Boys with a Nonpalpable Testis." Pediatrics 110 (4): 74-4.

[11] Nijs, S. M., Eijsbouts, S. W., Madern, G. C., Laymen, M. M., Lequin, H. M., and Hazebroek, W. J. 2007. "Nonpalpable Testes: Is There a Relationship between Ultrasonographic and Operative Findings?" Pediatr. Radiol. 37 (4): 374-9. 
[12] Ekenze, S. O., Nwankwo, E. P., and Okere, P. C. 2013. "The Utility of Ultrasonography in the Management of Undescended Testis in a Developing Country." World J. Surg. 37 (5): 1121-4.

[13] Sharifiaghdas, F., and Beigi, F. M. 2008. "Impalpable Testis: Laparoscopy or Inguinal Canal Exploration?" Scand. J. Urol. Nephrol. 42 (2): 154-7.

[14] Cain, M. P., Garra, B., and Gibbons, M. D. 1996. "Scrotal-Inguinal Ultrasonography: A Technique for Identifying the Nonpalpable Inguinal Testis without Laparoscopy." J. Urol. 156 (2 Pt 2): 791-4.

[15] Tasian, G. E., and Copp, H. L. 2011. "Diagnostic Performance of Ultrasound in Nonpalpable Cryptorchism: A Systematic Review and Meta-Analysis." Pediatrics 127 (1): 119-10.

[16] Shoukry, M., Pojak, K., and Choudhry, M. S. 2015. "Cryptorchidism and Value of Ultrasound Scan." Annals of the Royal College of Surgeons of England 97: 56-3.

[17] Adesanya, O. A., Ademuyiwa, A. O., Bode, C. O., and Adeyomoye, A. A. 2014. "Preoperative Localization of Undescended Testes in Children: Comparison of Clinical Examination and Ultrasonography." J. Paediatr. Urology 10 (2): 237-4.

[18] Aso, C., Enríquez, G., Fité, M., Torán, N., Piró, C., Piqueras, J., and Lucaya, J. 2005. "Gray-Scale and Colour Doppler Sonography of Scrotal Disorders in Children: An Update.” Radiographics 25 (5): 1197-18.

[19] Munden, M. M., and Trautwein, L. M. 2000. "Scrotal Pathology in Pediatrics with Sonographic Imaging." Curr. Probl. Diagn. Radiol. 29 (6): 185-21.

[20] McAlister, W. H., and Sisler, C. L. 1990. "Use of Scrotal Sonography in Infants and Children." Curr. Probl. Diagn. Radiol. 19 (6): 201-42.

[21] Yeung, C. K., Tam, Y. H., Chan, Y. L., Lee, K. H., and Metreweli, C. 1999. "A New Management Algorithm for Impalpable Undescended Testis with Gadolinium Enhanced Magnetic Resonance Angiography." J. Urol. 162 (3Pt2): 998-5.

[22] Maghnie, M., Vanzulli, A., Paesano, P., Bragheri, R., Palladini, G., Preti, P., Del Maschio, A., and Severi, F. 1994. "The Accuracy of Magnetic Resonance Imaging and Ultrasonography Compared with Surgical Findings in the Localization of the Undescended Testis." Arch. Pediatr. Adolesc. Med. 148 (7): 699-5.

[23] Shah, A., and Shah, A. 2006. "Impalpable Testes: Is Imaging Really Helpful?” Indian Pediatr. 43 (8): 720-3.

[24] Kanemoto, K., Hayashi, Y., Kojima, Y., Maruyama, T., Ito, M., and Kohri, K. 2005. "Accuracy of
Ultrasonography and Magnetic Resonance Imaging in the Diagnosis of Non-palpable Testis.” Int. J. Urol. 12 (7): 668-5.

[25] Wolverson, M. K., Houttuin, E., Heiberg, E., Sundaram, M., and Shields, J. B. 1983. "Comparison of Computed Tomography with High-resolution Real-time Ultrasound in the Localisation of the Impalpable Undescended Testis." Radiology 146 (1): 133-6.

[26] Hrebinko, R. L., and Bellinger, M. F. 1993. "The Limited Role of Imaging Techniques in Managing Children with Undescended Testes.” J. Urol. 150 (2 Pt 1): 458-3.

[27] Liu, C. S., Chin, T. W., and Wei, C. F. 2002. "Impalpable Cryptorchidism: A Review of 170 Testes." Chinese Medical Journal (Taipei) 65 (2): 63-8.

[28] National Guideline Clearinghouse (NGC). 2011. "Guideline Summary: Guideline on Paediatric Urology.' Accessed June 22, 2011. http//www.guideline.gov.

[29] Elder, J. S. 2011. "Why Do Our Colleagues Still Image for Cryptorchidism? Ignoring the Evidence." The Journal of Urology 185: 1566-2.

[30] Esposito, C., Caldamone, A. A., Settimi, A., and El-Ghoneimi, A. 2008. "Management of Boys with Nonpalpable Undescended Testis." Nature Clinical Practice Urology 5 (5): 252-8.

[31] Johansen, T. E., and Larmo, A. 1988. "Position of an UDT Is of Importance for Choice of Therapy." Acta Radiol. 29 (2): $159-5$.

[32] Budianto, I. R., Tan, H. L., Kinoshita, Y., Tamba, R. P., Leiri, S., and Taguchi, T. 2014. "Role of Laparoscopy and Ultrasound in the Management of "Impalpable Testis" in Children.” Asian J. Surg. 37 (4): 200-4.

[33] Ismail, K., Ashour, M., El-Afifi, M., Hashish, A., El-Dosouky, N., Nagm, M., and Hashish, M. 2009. "Laparoscopy in the Management of Impalpable Testes." World J. Surg. 33 (7): 1514-9.

[34] Al-Shareef, Z. H., Al-Shlash, S., Koneru, S. R., Towu, E., Al-Dhohayan, A., and Al-Brekett, K. 1996. "Laparoscopy Was Utilised in the Evaluation of Non-papable UDT." Ann. R. Coll. Surg. Engl. 78 (2): 115-8.

[35] Satar, N., Bayazit, Y., and Doran, S. 2005. "Role of Laparoscopy in the Management of Impalpable UDT Not Ultrasonography and/or Computed Tomography Are Not Informative Enough." Acta Chir. Belg. 105 (6): 662-6.

[36] Afzal, S., Bilal, M., Sarfraz, A., Lubna, I., Kanchan, K., and Shahid, I. 2012. "Laparoscopic Management of 128 Undescended Testes: Our Experience.” African Journal of Paediatric Surgery. 9 (2): 106-3. 